\title{
Splenic marginal zone lymphoma with autoimmune hemolytic anemia
}

\author{
Jay Suriar ${ }^{1}$, Mra Aye ${ }^{2 *}$, Mohamed M Musadiq ${ }^{3}$ and Jason S Cabot ${ }^{4}$ \\ ${ }^{1}$ Department of Hematology, Gleneagles Hospital Kuala Lumpur, Malaysia \\ ${ }^{2}$ Department of Medicine, Melaka Manipal Medical College, Melaka, Malaysia \\ ${ }^{3}$ Melaka Manipal Medical College, Melaka, Malaysia \\ ${ }^{4}$ Department of Hematology/Oncology, Cancer Center of Guam, Tamuning, Guam, USA
}

\begin{abstract}
Splenic Marginal Zone Lymphoma (SMZL) is an Unusual, distinct lymphoma characterized by indolent clinical course and prolonged survival, and having some clinical, cellular and immunophenotypical features that differ from other indolent lymphomas. We describe a case of SMZL that presented with autoimmune hemolytic anemia.
\end{abstract}

\section{Introduction}

SMZL was originally recognized either by histopathologic examination of splenectomised specimens [1] or by morphologic and immunophenotypical characterization of circulating neoplastic lymphocytes as splenic lymphoma with villous lymphocytes. SMZL is rare; accounting for $20 \%$ of all MZL, only $1 \%$ of non-Hodgkin's Lymphoma in adults [2] and mainly affecting elderly or middleaged patients, with median age of 65 years. SMZL is characterized by massive splenomegaly without significant lymphadenopathy, other than in the splenic hilum, and no other extranodal involvement other than bone marrow and liver [3], frequently with cytopenias and lymphocytosis [3]. There is no specific immunophenotypic marker for SMZL, with lymphoma cells expressing pan-B-cell antigens, usually CD20, CD45RA, CD45RB, CD79a, PAX5/BSAP, IgM, and surface IgM and/or Ig D, but negative for CD5, CD10, and CD23, CD43, bc16 and cyclin D1. B symptoms (weight loss, night sweats, fever) are rare [3-5].

Bone marrow and blood involvement are usually present in $95 \%$ in SMZL with villous lymphocytes present in blood in $15 \%$ of cases $[3,6]$. Different types of bone marrow infiltrations are described, namely intrasinusoidal, interstitial, nodular, and paratrabecular. Intrasinusoidal infiltration is considered highly characteristic of SMZL, and to date, apart from subtle infiltration in some extra nodal marginal lymphoma there have been no reports of intrasinusoidal infiltration in other kinds of low-grade B-cell lymphoma [7-11]. With peripheral blood involvement, numerous mature B lymphocytes with pale cytoplasm, irregular cytoplasmic borders, and villous projections can easily be recognized [12]. The co-occurrence of Hepatitis C (HCV) infection is of major importance due to possible therapeutic implications [13]. The precise pathogenesis of SMZL is unknown. In contrast to the well-established chromosomal changes associated with other B-cell NHL, few genetic alterations have been reported in SMZL [14]. In addition, SMZL may manifest autoimmune phenomena, with primary biliary cirrhosis [15], rheumatoid arthritis [16], immune thrombocytopenia, presence of lupus anticoagulant and autoimmune hemolytic anemia being the most frequent associated conditions.
There is no consensual standardized treatment for SMZL due to the lack of prospective randomized trials, the relative rarity of the disease and the prolonged survival. These include active surveillance, splenectomy, chemotherapy with rituximab alone and rituximab added to a variety of cytotoxic agents (chemo-immunotherapy) in various protocols. When concurrent $\mathrm{HCV}$ infection is present, this should be eradicated with newer direct acting anti-viral agents, and when chemotherapy is used, active or previous infection with Hepatitis $\mathrm{B}(\mathrm{HBV})$, should be treated with viral suppressive agents.

\section{Case presentation}

A 65-year-old Chinese man presented with lethargy and NYHA grade 2 dyspnea with only significant medical history of right knee joint replacement for osteoarthritis and recently diagnosed with HBV infection. He denied palpitation, central chest pain, cough, wheeze, fever and peripheral edema. He denied use of any illicit drugs, tobacco, and alcohol. Family history was noncontributory, including the absence of any malignancy.

On physical examination, the patient was lethargic, pale with tinge of jaundice, with vital signs on initial examination of tachycardia, but normal blood pressure. Abdominal examination revealed marked splenomegaly about $15 \mathrm{~cm}$ below the left costal margin with no abdominal tenderness. There were no other positive findings including no palpable adenopathy. Complete blood count (CBC) showed hemoglobin $5.41 \mathrm{~g} / \mathrm{dl}$ (normal range: 13-18), RBC $1.28 \times 10^{9} / \mathrm{L}(4.5-$ 6.5), hematocrit 15\% (40-54)\%), MCV(Mean Corpuscular Volume

Correspondence to: Mra Aye, Department of Medicine, Melaka Manipal Medical College,Melaka, Malaysia, E-mail: mraaye@hotmail.com

Key words: splenic marginal zone lymphoma, autoimmune manifestation, Rituximab

Received: February 26, 2018; Accepted: March 26, 2018; Published: March 31,2018 
116fl (76-96), WBC $11.3 \times 10^{9} / \mathrm{L}$ ( 4-11), Neutrophil $2.6 \times 10^{9} / \mathrm{L}(2-$ 7.5), Lymphocyte: $8.0 \times 10^{9} / \mathrm{L}(1.5-4)$, platelets $135 \times 10^{9} / \mathrm{L}(150-400)$, reticulocyte count: $13.6 \%(0.2-2)$, Lactate Dehydrogenase (LDH) 570 IU/L (81-234), total bilirubin $51.3(<22)$ with direct bilirubin 13.1 (0.0-5.0) and indirect bilirubin $38.1 \mathrm{umol} / \mathrm{L}$ (Table 1 and Figure 1). Peripheral blood film revealed minor agglutination of red blood cells with polychromasia without increase in spherocytes. WBC showed lymphocytosis with many lymphocytes showing villous cytoplasm and platelets were morphologically normal but slightly reduced. (Table 2) The direct antiglobulin test (Coombs direct) was strongly positive and monospecific for IgG and Anti -C3d with $3+$ and $2+$ reaction respectively.

Bone marrow aspiration and biopsy from the posterior iliac crest demonstrated erythroid hyperplasia, normal maturation of granulocytic series with morphologically abnormal lymphocytes demonstrating cytoplasmic villous projection (Figure 2), erythroid hyperplasia with left shifted maturation, with reduced myelopoiesis and megakaryopoiesis. Bone marrow aspiration biopsy stained with CD20 demonstrated an infiltrate of small lymphoid cells positive for CD20, CD79a, kappa light chain and negative for CD3, CD5, CD10, Tdt, CD23 and CD34. Microscopically there were lymphoid cells showing interstitial and paratrabecular nodules (Figure 3).

Abdominal Ultrasonography demonstrated a markedly enlarged spleen of $22.9 \mathrm{~cm}$ and a small $0.5 \mathrm{~cm}$ gall bladder polyp. Contrast Enhanced Computed Tomography (CECT) of the neck, thorax, abdomen and pelvis, apart from massive splenomegaly, (Figure 4) revealed no adenopathy except for minimally enlarged para aortic lymph nodes with largest measuring $1.3 \times 1.1 \mathrm{~cm}$ at the level of L3/ L4 intervertebral disc and an enlarged prostate of $3.7 \times 5.1 \times 3.2 \mathrm{~cm}$. Hepatitis B core antibody was reactive with undetectable HBS antigen and Hepatitis $\mathrm{C}$ antibody. Serum protein electrophoresis demonstrated reduced alpha 2 globulins, no paraproteins, and elevated free kappa light chains. Free serum Kappa was $82.08 \mathrm{mg} / \mathrm{L}$ (normal range 3.3019.40), Free Lambda $32.98 \mathrm{mg} / \mathrm{L}$ (normal range: $5.71-26.3$ ) and ratio of Kappa/Lambda high at 2.488. MYD88 p. Leu265Pro mutation was negative.
A diagnosis of autoimmune hemolytic anemia (AIHA) secondary to SMZL was made. Corticosteroids at $1 \mathrm{mg} / \mathrm{kg}$ with folate supplements were commenced and the patient was started on 6 weekly doses of rituximab at $375 \mathrm{mg} / \mathrm{m}^{2}$ as the patient refused splenectomy. Because of presence of Hepatitis B core antibody and treatment with rituximab and steroids, prophylactic Tenofovir was commenced to avert a Hepatitis B flare. Splenomegaly and signs of hemolysis rapidly improved. Hemolysis abated and CBC improved rapidly (Table 1 and Figure 1 ) and rapid steroid taper was instituted after $2^{\text {nd }}$ week of treatment. Repeat CT abdomen in follow-up clinic revealed spleen size of $9 \mathrm{~cm}$ after only two rituximab injections (Figure 5).

There were no adverse reactions to rituximab and at present, with maintenance rituximab $375 \mathrm{mgmg} / \mathrm{m}^{2}$ every two months the patient continues in apparent complete remission. Repeat Coomb's test (polyspecific test) was $3+$ and $2+$ after $4^{\text {th }}$ and $5^{\text {th }}$ month of rituximab and Monospecific Coomb's test was IgG0 and antiCd31+ after $7^{\text {th }}$ month of rituximab. His Hepatitis B status was within control as he did develop any signs or symptoms of exacerbation.

Rituximab maintenance 500 mg every 2 months for $1-2$ years was planned. Subsequent CBC's and parameters of hemolysis are shown in Table 3 and Figure 6. Patient has been well since completion of $2^{\text {nd }}$ dose of rituximab and after $5^{\text {th }}$ month of treatment his performance status has been fully normal, and he has been playing rugby.

\section{Discussion}

The diagnosis of hemolysis was based on complete blood count, reticulocyte count, higher indirect than direct bilirubin, high LHD, and serological evidence of an autoantibody. The finding of a positive direct antiglobulin test (DAT), also called direct Coombs, in the setting of hemolytic anemia is diagnostic of AIHA [17]. Positive DAT for autoantibodies against IgG (warm AIHA) and anti C3d in our patient was consistent with mixed warm/cold AIHA [18]. In older patients, $90 \%$ of AIHA occurs secondary to an underlying B-cell lymphoproliferative disorder; most commonly MZL or LPL. Massive splenomegaly is not compatible with idiopathic AIHA; and presence of significant splenomegaly should raise concern of underlying lymphoma [19].

Table 1. CBC, hemolytic parameters free light chains and liver function tests.

\begin{tabular}{|c|c|c|c|c|c|c|}
\hline & Normal range & Unit & $\begin{array}{c}\text { Admitted on 28.06.17, } \\
\text { rituximub started on } \\
\text { 30.03.17 }\end{array}$ & 5.07 .17 & 20.07.17 & 31.08.17 \\
\hline $\mathrm{Hb}$ & $13.0-18.0$ & $\mathrm{~g} / \mathrm{dL}$ & 5.4 & 10.4 & 11.6 & 12.2 \\
\hline $\mathrm{RBC}$ & $4.5-6.5$ & $\times 10^{12} / \mathrm{L}$ & 1.28 & 2.34 & 3.06 & 3.86 \\
\hline PCV & $40-54$ & $\%$ & 15 & 23 & 30 & 38 \\
\hline $\mathrm{MCV}$ & $76-96$ & $\mathrm{fL}$ & 116 & 100 & 98 & 97 \\
\hline WBC & $4.0-11.0$ & $\times 10^{9} / \mathrm{L}$ & 11.3 & 9.0 & 7.8 & 5.8 \\
\hline NEU & $2.0-7.5$ & $\times 10^{9} / \mathrm{L}$ & 2.6 & 2.9 & 3.4 & 3.7 \\
\hline LYMPHO & $1.5-4.0$ & $\times 10^{9} / \mathrm{L}$ & 8.0 & 6.2 & 5.9 & 1.6 \\
\hline PLATELETS & $150-400$ & $\times 10^{9} / \mathrm{L}$ & 135 & 133 & 145 & 179 \\
\hline RETICULO & $0.2-2.0$ & $\%$ & 13.6 & 15.9 & 10.1 & 1.6 \\
\hline LDH & $81-234$ & $\mathrm{U} / \mathrm{L}$ & 570 & 389 & 303 & 250 \\
\hline $\begin{array}{l}\text { Coomb's test } \\
\text { Monospecific }\end{array}$ & & & $\begin{array}{c}\mathrm{IgG} 3+ \\
\text { AntiC3d2+ }\end{array}$ & & & \\
\hline Serum Free Kappa & $3.30-19.4$ & $\mathrm{mg} / \mathrm{L}$ & 82.08 & & & \\
\hline $\begin{array}{l}\text { Serum Free } \\
\text { Lambda }\end{array}$ & $5.71-26.30$ & $\mathrm{mg} / \mathrm{L}$ & 32.98 & & & \\
\hline ALBUMIN & $32-48$ & $\mathrm{~g} / \mathrm{L}$ & 40 & - & & \\
\hline GLOBULIN & $20-50$ & $\mathrm{~g} / \mathrm{L}$ & 32 & - & & \\
\hline TOTAL BILIRUBIN & $(<22.0)$ & umol/L & 51.3 & 23.4 & 16.8 & \\
\hline DIRECT BILIRUBIN & $0.0-5.0$ & umol/L & 13.1 & 7.3 & 6.1 & \\
\hline
\end{tabular}


Diagnosis of SMZL is based on clinical, morphological, immunophenotying, and bone marrow biopsy, (unusually with splenic biopsy) as there are many features in common between SMZL, hairy cell lymphoma, follicular cell lymphoma, mantle cell lymphoma, B-chronic lymphatic leukemia and lymphoplasmocytic lymphoma (LPL) or Waldenstrom Macroglobulinemia. Diagnosis of SMZL here was made by presence the following features: massive splenomegaly, presence of AIHA, absence of clinical peripheral lymphadenopathy, sinusoidal pattern of infiltration coupled with an interstitial or nodular component on marrow biopsy, appropriate positive and negative

\section{PARAMETERS OF HEMOLYSIS DURING THE ADMISSION}

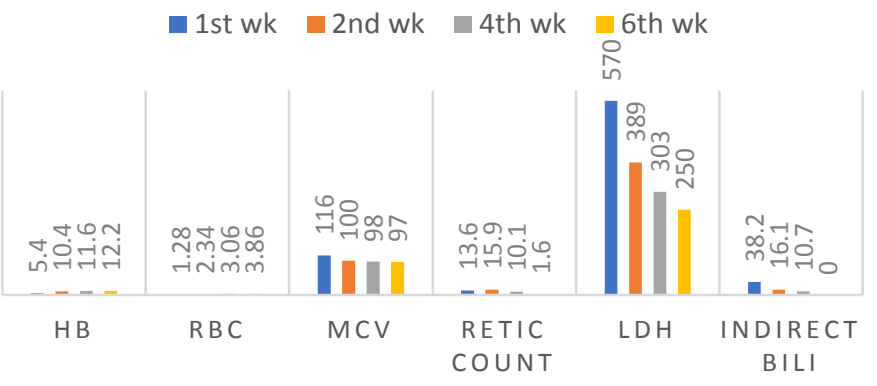

Figure 1. Hemoglobin $(\mathrm{g} / \mathrm{dl})$, Red blood cell count $\times 109$, MCV(fl), Reticulocyte count $(\%), \mathrm{LDH}(\mathrm{IU} / \mathrm{L})$ and Indirect bilirubin (umol/L) before and after rituximab.

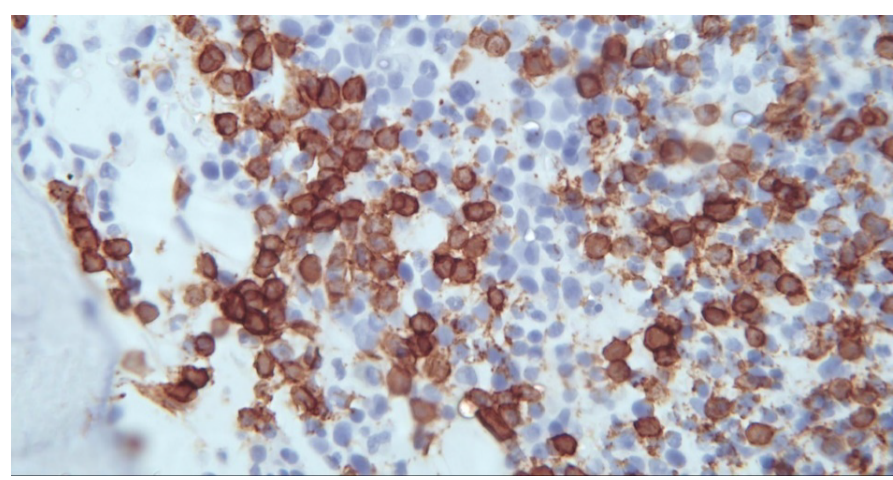

Figure 2. Lymphocytes with villous projections in bone marrow aspiration.

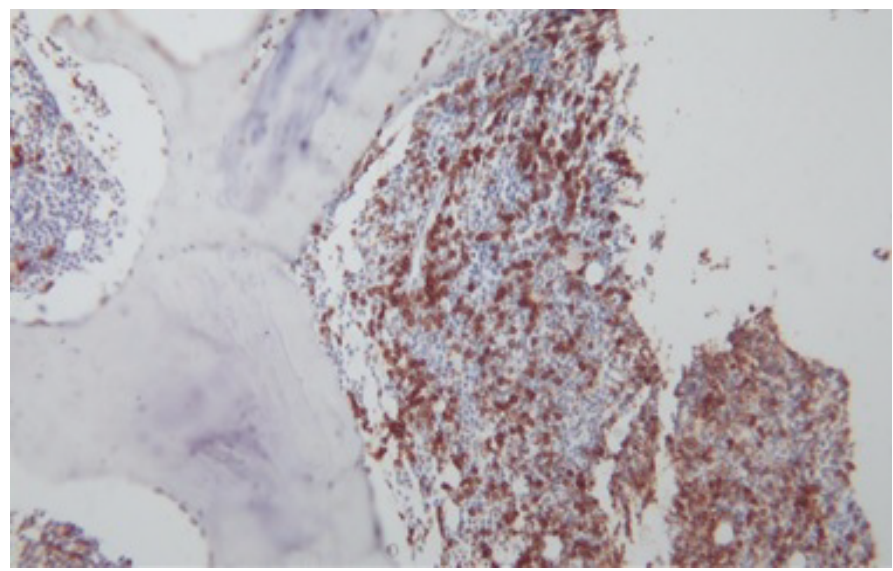

Figure 3. Bone marrow trephine biopsy with CD 20 stain.

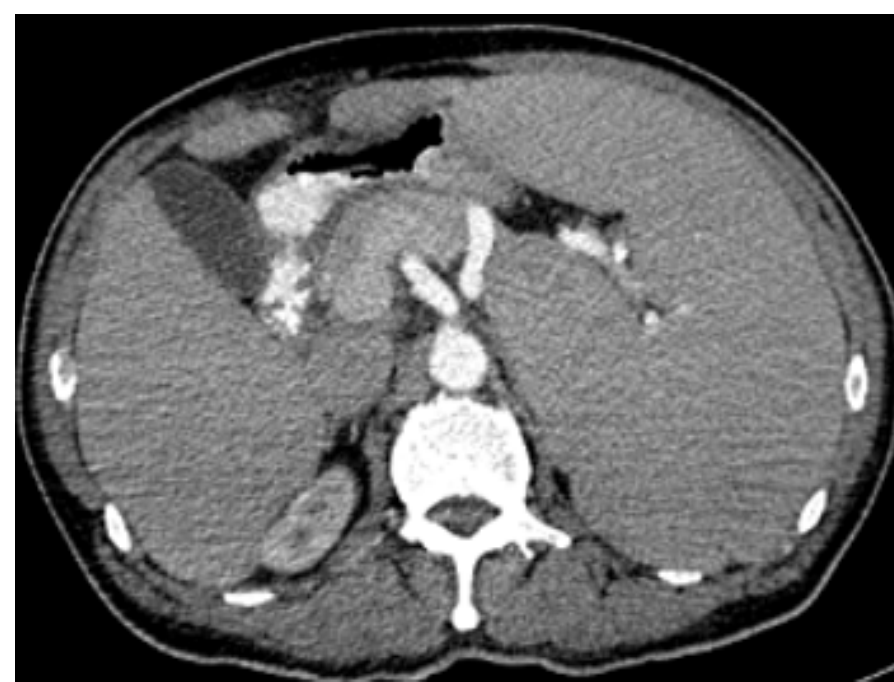

Figure 4. CT abdomen showing spleen size before Rituximab.

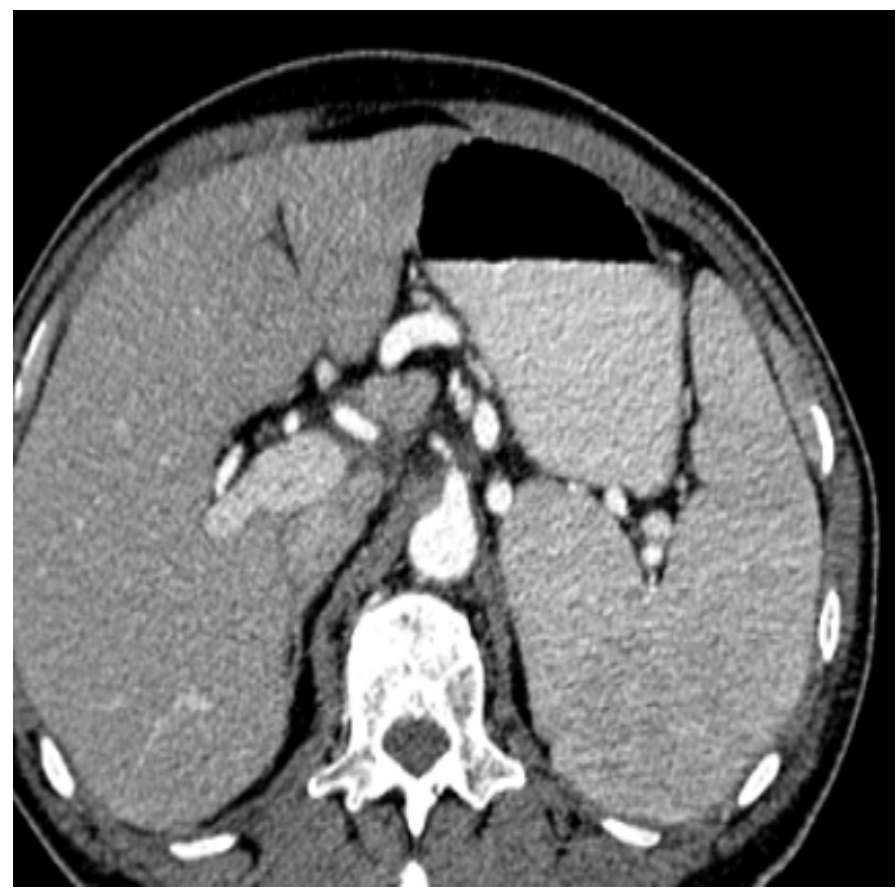

Figure 5. CT abdomen showing reduction of spleen size after two injections of Rituximab.

\section{PARAMETERS OF HEMOLYSIS ADFTER DISCHARGE}

10th wk $\quad 14$ th wk $\square 18 \mathrm{wk} \quad$ 24th wk

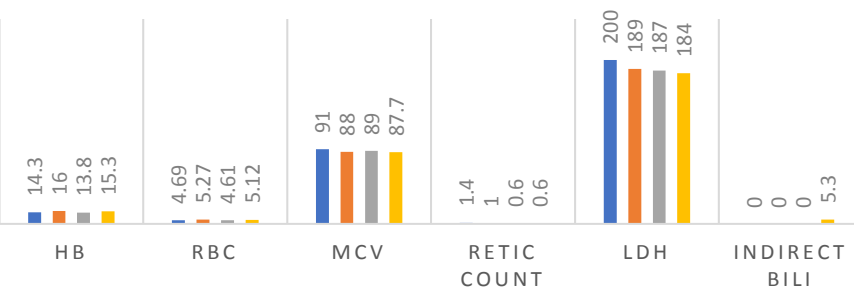

Figure 6. Hemoglobin (g/dl), Red blood cell count x 10\%, MCV (fl), Reticuocyte count (\%), LDH (IU/L) and Indirect bilirubin (umol/L) before and after Rituximab during admission. 
Table 2. Report of peripheral blood, bone marrow, immunocytochemistry and flow cytometry.

\begin{tabular}{|l|l|l|}
\hline Peripheral blood film & Findings & Comments \\
\hline Bone marrow trephine biopsy & $\begin{array}{l}\text { RBC: minor agglutination, polychromasia without increase in spherocytes } \\
\text { WBC: Lymphocytosis with many lymphocytes showing villous cytoplasm. } \\
\text { Platelets: mildly reduced, but normal morphologically }\end{array}$ \\
\hline Immunocytochemistry of bone marrow & $\begin{array}{l}\text { The marrow is patchily hypercellular, infiltrated by groups of small to } \\
\text { medium sized lymphoid cells surrounded by other haemopoietic cells. } \\
\text { The lymphoid cells show interstitial distribution as well as central and } \\
\text { paratrabecular nodules. }\end{array}$ \\
\hline Flow cytometry of bone marrow report & $\begin{array}{l}\text { The cells are positive for CD20, CD79a and kappa light chain. CD 20 shows } \\
\text { that the lymphoid cells occupy more than 30\% of cell volume. They are } \\
\text { negative for CD3, CD5, CD10, CD23, CD34, cyclin D1, CD138 and TdT } \\
\text { and CD34 }\end{array}$ \\
\hline $\begin{array}{l}\text { Low grade B cell lymphoma, compatible with } \\
\text { splenic marginal lymphoma }\end{array}$ & $\begin{array}{l}\text { Positive markers: CD19, CD 79a, HLA-DR, Bright CD20, FMC7, sIgM, } \\
\text { sIgD and sIgM Negative markers: CD25, CD34, CD38, CD43, CD5, CD10, } \\
\text { CD103, sIgG lambda }\end{array}$ & $\begin{array}{l}\text { There is infiltration of the marrow by a clonal } \\
\text { and immunophenotiferative disorder. The morphological } \\
\text { with a Splenic Marginal Zone Lymphoma }\end{array}$ \\
\hline
\end{tabular}

Table 3. Full blood count and other parameters of hemolysis after discharge or during follow up.

\begin{tabular}{|c|c|c|c|c|c|c|c|}
\hline & Normal range & Unit & $\begin{array}{c}2 \text { months after } \\
\text { treatment } \\
31.08 .17\end{array}$ & $\begin{array}{c}3 \text { months after } \\
\text { treatment } \\
30.09 .17\end{array}$ & $\begin{array}{c}4 \text { months after } \\
\text { treatment } \\
31.10 .17\end{array}$ & $\begin{array}{c}5 \text { months after } \\
\text { treatment } \\
1.12 .18\end{array}$ & $\begin{array}{c}6 \text { months after } \\
\text { treatment }\end{array}$ \\
\hline $\mathrm{Hb}$ & $13.0-18.0$ & $\mathrm{~g} / \mathrm{dL}$ & 14.3 & 16.0 & 13.8 & 15.3 & \\
\hline $\mathrm{RBC}$ & $4.5-6.5$ & $\times 10^{12} / \mathrm{L}$ & 4.69 & 5.27 & 4.61 & 5.12 & \\
\hline $\mathrm{PCV}$ & $40-54$ & $\%$ & 43 & 47 & 41 & 44.9 & \\
\hline $\mathrm{MCV}$ & $76-96$ & $\mathrm{fL}$ & 91 & 88 & 89 & 87.7 & \\
\hline WBC & $4.0-11.0$ & $\times 10^{9} / \mathrm{L}$ & 5.9 & 5.1 & 4.0 & 4.5 & \\
\hline NEU & $2.0-7.5$ & $\times 10^{9} / \mathrm{L}$ & 3.7 & 4.5 & 0.9 & 2.8 & \\
\hline LYMPHO & $1.5-4.0$ & $\times 10^{9} / \mathrm{L}$ & 1.7 & 0.5 & 0.9 & 1.3 & \\
\hline PLATELETS & $150-400$ & $\times 10^{9} / \mathrm{L}$ & 135 & 122 & 118 & 116 & \\
\hline RETICULO & $0.2-2.0$ & $\%$ & 1.4 & 1.0 & 0.6 & 0.6 & \\
\hline LDH & $81-234$ & $\mathrm{U} / \mathrm{L}$ & 200 & 189 & 187 & 184 & \\
\hline $\begin{array}{l}\text { Coomb's test } \\
\text { Polyspecific }\end{array}$ & & & & & $3+$ & $2+$ & \\
\hline $\begin{array}{l}\text { Coomb's test } \\
\text { Monospecific }\end{array}$ & & & & & & & $\begin{array}{c}\operatorname{IgG} 0 \\
\text { AntiCd31+ }\end{array}$ \\
\hline ALBUMIN & $32-48$ & $\mathrm{~g} / \mathrm{L}$ & - & - & & & \\
\hline GLOBULIN & $20-50$ & $\mathrm{~g} / \mathrm{L}$ & - & - & & & \\
\hline TOTAL BILIRUBIN & $(<22.0)$ & umol/L & - & - & & 10.7 & \\
\hline DIRECT BILIRUBIN & $0.0-5.0$ & $\mathrm{umol} / \mathrm{L}$ & - & - & - & 5.6 & \\
\hline
\end{tabular}

immunopheotypic features (positive markers: CD19, CD 29a, HLADR, Bright CD20, FMC7, sIgM, sIgD and sIgM, negative markers: CD5, CD10, CD25, CD34, CD38, CD43, CD103, sIgG lambda) and finally presence of AIHA [3-12].

Because of AIHA and massive splenomegaly, active surveillance was not appropriate. Splenectomy, the oldest active therapeutic approach, with its pros (prolonged remission with one procedure) and cons (feasibility, side effects, surgical morbidity and poor choice with significant bone marrow involvement), could also be diagnostic and can be usually safely performed using laparoscopy, demonstrating high short- and long-term efficacy. In some patients, such as those with AIHA associated with splenic marginal zone lymphoma, splenectomy could provide favorable overall survival [20]. Thieblemont et al., [21] stated that splenic marginal zone lymphoma is a rare subtype of non-Hodgkin lymphoma in which autoimmune manifestations, such as autoimmune hemolytic anemia with massive splenomegaly, are relatively common, our patient being such an example. In cases of steroid refractory AIHA with massive splenomegaly and uncertain pathologic diagnosis, splenectomy is recommended since it can usually ameliorate the anemia anb establish the diagnosis [22].

Rituximab monotherapy is equally effective with lesser side effects $[4,23]$ and has dual action on both AIHA and lymphoma remission with minimal apparent toxicity [24]. However, our patient was reactive to Hepatitis B core antibody and rituximab therapy risks revitalization of hepatitis B virus. The option of splenectomy was offered but refused by patient. Therefore, rituximab monotherapy was instituted with corticosteroids and HBV prophylaxis with Tenofovir. Three weeks after admission, hemolysis abated, hemoglobin rapidly increased and bilirubin, MCV and LDH decreased toward normal ranges, allowing the rapid taper of corticosteroid therapy during the second week. Spleen size decreased remarkably after two injections of rituximab and lymphocyte counts decreased to normal.

\section{Conclusion}

SMZL, a relatively rare lymphoma, usually has an indolent clinical course with prolonged survival. Active surveillance can be a strategy for relatively asymptomatic patients, with splenectomy in select individuals and immunotherapy or chemo-immunotherapy for the majority. Our patient was treated with rituximab monotherapy for both lymphoma and secondary AIHA and had a rapid response.

\section{References}

1. Schmid C, Kirkham N, Diss T, Isaacson PG (1992) Splenic marginal zone cell lymphoma. Am J Surg Pathol 16: 455-466. [Crossref]

2. Berger F, Felman P, Thieblemont C, Pradier T, Baseggio L, et al. (2000) Non-MALT marginal zone B-cell lymphomas: a description of clinical presentation and outcome in 124 patients. Blood 95: 1950-1956. [Crossref] 
3. Thieblemont C, Davi F, Noguera M (2012) Splenic Marginal Zone Lymphoma: Current Knowledge and Future Directions. Oncology Journal. 26: 194-202. [Crossref]

4. Kalpadakis C, Pangalis GA, Angelopoulou MK (2017) Treatment of splenic marginal zone lymphoma. Progress report and comparison with splenectomy. Best Pract Res Clin Haematol 30: 139-148.

5. Goede V (2017) Marginal Zone Lymphoma in elderly and geriatric patients. Best Pract Res Clin Haematol 30:158-165.

6. Tsimberidou AM, Catovsky D, Schlette E (2006) Outcomes in patients with splenic marginal zone lymphoma and marginal zone lymphoma treated with rituximab with or without chemotherapy or chemotherapy alone. Cancer 107: 125-135. [Crossref]

7. Franco V, Florena AM, Campesi G (1996) Intrasinusoidal bone marrow infiltration: a possible hallmark of splenic lymphoma. Histopathology 29: 571-575. [Crossref]

8. Labouyrie E, Marit G, Vial J (1997) Intrasinusoidal bone marrow involvement by splenic lymphoma with villous lymphocytes: a helpful immunohistologic feature. Mod Pathol 10:1015-1102. [Crossref]

9. Berger F, Felman P, Thieblemont C, Pradier T, Baseggio L, et al. (2000) Non-MALT marginal zone B-cell lymphomas: a description of clinical presentation and outcome in 124 patients. Blood 95: 1950-1956. [Crossref]

10. Hammer RD, Glick AD, Greer JP, Collins RD, Cousar JB (1996) Splenic margina zone lymphoma. A distinct B-cell neoplasm. Am J Surg Pathol 20: 613-626. [Crossref]

11. Kent SA, Variakojis D, Peterson LC (2002) Comparative study of marginal zone lymphoma involving bone marrow. Am J Clin Pathol 117: 698-708. [Crossref]

12. Lloret E, Mollejo M, Mateo MS (1999) Splenic marginal zone lymphoma with increased number of blasts: an aggressive variant? Hum Pathol 30: 1153-1160. [Crossref]

13. Hermine O, Lefrere F, Bronowicki J (2002) Regression of splenic lymphoma with villous lymphocytes after treatment of hepatitis C virus infection. $N$ Engl J Med 11: 89-94. [Crossref]
14. Miranda RN, Cousar JB, Hammer RD (1999) Somatic mutation analysis of IgH variable regions reveals that tumor cells of most parafollicular (monocytoid) B-cell lymphoma, splenic marginal zone B-cell lymphoma, and some hairy cell leukemia are composed of memory B lymphocytes. Hum Pathol 30: 306-312. [Crossref]

15. de Figueiredo M, Lima M, Macedo G (1996) Association of splenic lymphoma with villous lymphocytes and primary biliary cirrhosis in a man. Sangre (Barc) 41: 262-263. [Crossref]

16. Takai K, Sanada M, Shibuya H (1993) Primary splenic lymphoma complicated by malignant rheumatoid arthritis and bladder cancer. Rinsho Ketsueki 34: 79-83.

17. Gehrs BC, Freidberg RC (2002) Autoimmune Hemolytic Anemia. American Journal of Hematology 69: 258-271.

18. DeLoughery TG (2013) Autoimmune Hemolytic Anemia. Board Review Manual Hematology 8: Part 1 www.hpboardreview.com

19. Sallah GS, Sigounas P, Vos JY (2000) Autoimmune hemolytic anemia in patients with non-Hodgkin's lymphoma: Characteristics and significance. Annals of Oncology 11 1571-1577. [Crossref]

20. Xing KH, Kahlon A, Skinnider BF (2015) Outcomes in splenic marginal zone lymphoma: analysis of 107 patients treated in British Columbia. Br J Haematol 169: 520-527. [Crossref]

21. Thieblemont C, Felman P, Callet-Bauchu E, Traverse-Glehen A, Salles G, et al. (2003) Splenic marginal-zone lymphoma: a distinct clinical and pathological entity. Lancet Oncol 4: 95-103. [Crossref]

22. Ureshino H, Miyahara M (2017) Steroid-Refractory Autoimmune Hemolytic Anemia with Massive Splenomegaly. Am J Med 130: e393-393e394. [Crossref]

23. Bennett M, Schechter GP (2010) Treatment of Splenic Marginal Zone Lymphoma: Splenectomy Versus Rituximab. Seminars in Hematology 47: 143-147.

24. Kalpadakis C, Pangalis GA, Dimopoulou MN, Vassilakopoulos TP, Kyrtsonis MC et al. (2007) Rituximab monotherapy is highly effective in splenic marginal zone lymphoma. Hematol Oncol 25: 127-131. [Crossref]

Copyright: $\odot 2018$ Suriar J. This is an open-access article distributed under the terms of the Creative Commons Attribution License, which permits unrestricted use, distribution, and reproduction in any medium, provided the original author and source are credited. 